\title{
Mobility and Infrastructure in the Russian Arctic
} Das Sein bestimmt das Bewusstsein?

\author{
NIKOLAI VAKHTIN
}

\begin{abstract}
This special issue approaches the interrelated themes of mobility and infrastructure in the Russian Arctic. I will discuss the general topics covered in this set of articles and how these contributions help us understand the lives of people in northern Siberia today, and I will give some context on how these articles came about in the first place. Does being determine consciousness? Or does consciousness determine being? This special issue looks at the complex interplay between people's perception of well-being and behavior, and their understanding and discourse around infrastructure. Several case studies examine the tension between perception, mobility, and infrastructure in communities across the Russian Arctic.
\end{abstract}

Keywords: infrastructure, interpretation, Latour, mobility, networks, remoteness

his special issue of Sibirica arose from a 2015 panel that was part of the annual conference at the European University at St. Petersburg (EUSP). The panel-Mobility and Infrastructure in the Russian Arctic: Das Sein bestimmt das Bewusstsein?1—-dealt with relationships between (mostly Arctic) infrastructures and (mostly Arctic) societies. The main question of the panel, following Marx's formulation, was, to what extent do objective, measurable characteristics of the northern infrastructure determine behavior, attitudes toward, and assessment of, different aspects and elements of human lives in the Arctic? Similarly, how do the changes of infrastructural parameters influence the life of the Arctic communities? Conversely, is there evidence to show the inverse-that 
people's assessment and perception of their infrastructural situation is informed by their behavior and interactions?

The North and the Arctic are notoriously stereotyped as hard to get to and infrastructurally deficient. People who live in the Arctic are constantly challenged by questions like, How do I organize my life in the Arctic? How do I reach the mainland? Where do I buy mutton? How do I transfer money to my children who live in larger southern cities? How do I use the weak Internet connection to my maximum benefit? How do I get medical services? Where do I spend my holidays? To what university do I send my children? Where do I move after retirement? What do I do when I lose my job? How do I build a house when I live several thousand miles away from the construction site? And many others.

The underlying question was, "How do people assess infrastructure?" Apparently, it depends on a variety of social factors such as age, place of birth, gender, education level, family status (single, married, parents, how many children and of what age, etc.), as well as on individual characteristics of the person, but this seems to be only part of the story.

Alla Bolotova, Anastassia Karaseva, and Valeria Vasilyeva show in their article that different aspects of the infrastructure can be assessed differently. Some aspects may be regarded positively (for example, the feeling of security in a small settlement where everybody knows everybody else), while others may be seen as negative (for example, low salaries). The authors discuss a complicated balancing process that considers which aspect has greater weight and the types of deficit that may be compensated for by something else.

Compensating mechanisms emerge. How can we improve inadequate elements of the infrastructure, or, if we cannot, can we replace them with something else? For example, deficiencies in access to food and clothing supplies might be compensated for by developing and supporting complicated social networks that offer their members necessary services in exchange for similar services later. Inadequate or nonexistent public transportation can be substituted by public usage of private cars within a community, as described within Elena Liarskaya's article. An insufficient number of state-built winter snow roads can be complemented by illegal self-made snow roads that are built, operated, and used by members of the communities. Low salaries are compensated for with other kinds of subsistence, such as hunting and fishing, coupled with a broad exchange network. The village experiences a deficiency of coal; the inhabitants find a coal mountain in the vicinity and do their own small-scale coal mining. 
Second, even if we take an average assessment of the infrastructure as a whole and ask people to make the simplest possible assessment (is it good or bad?), the situation does not become simpler. It may seem that mobility intentions can be a clear, rational indicator. If the person wishes to leave the place, this means that the person assesses it negatively; if the person wishes to stay, this implies a positive assessment. However, Ksenia Gavrilova's article shows that the situation is far from simple. Two people can assess the same aspect of the infrastructure differently and put these opposite views forward as justification for their plans to leave or to stay. Two people can say about the same place, "I wish to leave because medical service here is very bad," or "I wish to stay because medical service here is very good." Moreover, the same person within the same conversation can offer opposite assessments of the same infrastructural aspect: "It is impossible to live here," and one hour later, "But I will never leave. I like it here." In other words, the assessment of infrastructural characteristics can become secondary in relation to the mobility intention: not "It is bad here so I wish to leave," but rather "I wish to leave - so it is bad here."

\section{Interlude}

Almost 25 years ago, in summer 1993, I took part in a large-scale research expedition organized by Prof. Boris Chichlo, then working at Centre National de la Recherche Scientifique (CNRS), Paris, that was sponsored by Swiss watch company Longines and called, somewhat clumsily, TransiBering-Longines. The name was supposed to indicate that the expedition was to go across all Siberia as far as the Bering Strait. As the sponsor's website still tells us, “L'expédition avec le nom 'TransiBering' voulait explorer la vie des personnes dans l'extrême nord-est de la Russie" [The TransiBering expedition intended to explore the lives of people in the far northeast of Russia]. So it did. Three powerful cross-country caterpillar vehicles, tugging sleighs packed with supplies and fuel, stubbornly crawled along the Arctic Circle all the way from the Ural Mountains to Chukotka, waiving the proud flag of Longines, stopping in every village to advertise the company and its expensive watches to the locals. I am afraid the villagers were more interested in the vehicles than in the watches, though they could hardly dream at the time of ever buying either. After this grand enterprise had been fully equipped and financed, there even remained some money to support a small, international group of researchers who moved from village to 
village by less exotic transport, including helicopters and the inevitable AN-2 slogger aircraft.

One day we arrived at an abandoned village on the Sakha shore of the Arctic Ocean. We learned that the inhabitants had abandoned it the previous year because of radioactive pollution from the Novaya Zemlya nuclear tests. The people had fled in panic, leaving their houses behind with everything inside: furniture, clothes, kitchen equipment, and toys.

One of our group, a geophysicist from Irkutsk, went to the shore with his radioactivity measuring device to see how bad the situation was and whether it was possible to spend the night there at all. He came back a couple of hours later, totally perplexed. "Nikolai, there is nothing. Just the natural level of radioactivity." Control measurements proved that this was true. The radioactive threat existed only in the minds of local authorities, local "green" activists, and journalists, who, in all probability, conveyed the bad news to the local people.

This was the first time I came across this paradox. What is the nature of this "nothing" that urged people to abandon their homes, leave behind their belongings, and flee? This was a vivid example of a case in which people explained their opinions, attitudes, motivations, and behavior by referring to material, objective facts, but in reality these facts existed only in their imagination. People were driven not by facts but by fears, hopes, myths, and stereotypes, and those do not seem to be less powerful constituents of the infrastructure and driving forces for mobility than pipelines, railways, food supplies, or the Internet connection.

$$
* \quad * \quad *
$$

This special issue opens with an article by Vladimir N. Davydov (Kunstkamera, St. Petersburg), “Temporality of Movements in the North: Pragmatic Use of Infrastructure and Reflexive Mobility of Evenkis and Dolgans." Focusing on indigenous people of the Taimyr and Baikal areas, the author deconstructs the dichotomies between sedentary and nomadic, and between the village and the surrounding tundra and taiga. Davydov describes how local people use the remnants of abandoned infrastructure to enhance their mobility and to make up for deficiencies of transport and communication.

Davydov's article is followed by one by Ksenia Gavrilova (EUSP), “Temporal Dimension of Attitudes toward Infrastructure and Opportunities for Relocation from the Northern Town (The Case of Kamchatka Krai)." Gavrilova writes that the classical "push and pull theory" does 
not always work in the Arctic. The relationship between the motivations to leave the North and actual migration is much more complex and cannot be described and understood within a simple pragmatic model. Perceptions of sufficient or insufficient infrastructure can be productively analyzed as a local discursive tradition that should be deconstructed, not objectivized. Depending on the intention "to stay or to leave" and the duration of one's stay in a settlement, the same features of the local infrastructure can be described as positive or negative.

Nadezhda Zamyatina (Moscow State University) in her article, "Migration Destination Choice as a Criterion of Self-Identification: The Case of Young People Leaving Norilsk and Dudinka," shows that the choice of migration direction is determined not so much by economic conditions and opportunities as by the potential migrant's self-assessment, system of values, and Weltanschauung. The research is based on extensive interviews with schoolchildren of the city of Norilsk, and it demonstrates how individual values can be indicative of attitudes toward migrating to a (big) city.

The article "Mobility and Sense of Place among Youth in the Russian Arctic" is based on three separate conference contributions. Alla Bolotova, Anastassia Karaseva, and Valeria Vasilyeva (all from EUSP) combine their data and give three case studies in a jointly authored text. Their case studies illustrate how different distinct parts of the Russian Arctic are and, at the same time, how one can compare them from the perspective of mobility and place perception. The authors compare Murmansk Oblast', the Central Kolyma area, and the eastern Taimyr Peninsula, and they analyze the mobility of younger generations against the degree of transport and communication infrastructure development of the three regions.

The concluding article by Elena Liarskaya (EUSP), “'Where Do You Get Fish?': Practices of Individual Supplies in Yamal as an Indicator of Social Processes," starts with what looks like a simple description of everyday life in harsh Arctic conditions. It is not the cold but the long distances, the insufficient supplies, and the sparse infrastructure that are regarded by the people as the hardest side of their life in the North. Using field data from Yamal, the author describes regular practices aimed at compensating infrastructural deficits through social networks. She demonstrates that, if regarded from this perspective, the communities in question appear to be more complicated in composition than a simple dichotomy of indigenous people versus newcomers. 
The general theoretical approach used by the authors of these articles is complex. Their approach lies at the intersection of four powerful concepts: mobility, remoteness, networks, and infrastructure. The first three are relatively clear; the fourth-infrastructure-is both the key concept of all the articles and ... a nightmare.

The authors of this special issue look at mobility from John Urry's (2000) classical perspective, which argues that sociology should switch its focus from the study of society to the study of physical and virtual movement, or mobilities: the travels of people, ideas, images, messages, waste products, and money that can flow across various scapes. Such mobilities are shaped by more than simple economic conditions and opportunities. The social networks of the prospective migrants are important, and, as Zamyatina argues in her article, so are selfassessments, worldviews, and value systems.

These ideas are based, among other things, on Manuel Castells' (1996) approach to networks and connections. Although Castells himself emphasized repeatedly that his theory was "not just about networks or social networks" but "about social networks which process and manage information and are using micro-electronic based technologies" (Castells 2001), his ideas are deeper and more broadly applicable than to networks organized around electronically processed information:

The topology defined by networks determines that the distance (or intensity and frequency of interaction) between two points (or social positions) is shorter (or more frequent, or more intense) if both points are nodes in a network than if they do not belong to the same network. ... The inclusion/exclusion in networks, and the architecture of relationships between networks ... configurate dominant processes and functions in our societies. (Castells 1996: 470)

Similarly, the relations between different intensively used places can be described as a meshwork (Ingold 2000), which helps to analyze local people's mobility patterns. In this sense, movement does not relate just to the points where it has started and finished, but it should be analyzed in relation to numerous points surrounding it. The concept of meshwork turns out to be rather powerful: it allows one to identify what Davydov calls points of constant return that are intensively used by local people. In particular points of constant return, one sees concentrations of people and infrastructure, intensification of mobility patterns, and the introduction of transport infrastructure and construction of new bases and settlements within development project frameworks. 
Bolotova, Karaseva, and Vasilyeva argue that despite increasing mobility under globalization, the majority of recent studies confirm that most people continue to maintain a strong place attachment. This sense of place is determined, in a nonlinear way, by the perception of remoteness, a concept widely used by social sciences in relation to the Far North. The authors follow Caroline Humphrey (2014), who has demonstrated that remoteness is not a characteristic of scale or space but rather a concept that allows one to represent a place depending on the level of its infrastructural development, primarily its transport facilities. Well-developed transportation infrastructure can influence the perception of place; local people have various instruments to compensate for its absence or shortage.

Remoteness is another seminal concept used by the authors of the present collection. "The lesson of 'remote' areas is that this is a condition not related to periphery, but to the fact that certain peripheries are by definition not properly linked to the dominant zone" (Ardener [1987] 2012: 532). As Davydov puts it, "Administrative practice inevitably divided space into a center and a periphery, but local people adapted to the new logistical schemes, which were based on this spatial logic, and combined the use of multiple points of constant return."

The interplay between mobility and infrastructure is discussed in Gavrilova's article. Commonly, sociologists and demographers see this as a simple cause-and-effect relation: good and developed infrastructure attracts people and causes them to stay, while poor and insufficient infrastructure promotes out-migration. Gavrilova argues that this relation is not a straightforward one: the infrastructure of a settlement is assessed as good or poor depending on how long the person has lived there. Moreover, the same infrastructure is often described as poor by those who are planning to leave, and as quite sufficient (or at least as being easily supplemented) by those who are planning to stay.

This brings us to the fourth prevailing concept used by the authors of the present collection: infrastructure. Today, the use of the concept of infrastructure is consistent with John Urry's concept of scapes as networks of technology, organizations, actors, and texts that exist in the forms of travel-, business-, media-, and discourse-scapes (2000: 35). The concept of infrastructure has, thus, turned into a pervasive umbrella term under which more and more is considered. One has a feeling of watching a contest in ingenuity for who will add one more shade of meaning to the term.

In all probability, everything began with Latour. Latour's (1988, 1996) practical research in science and technology studies later 
developed into actor-network theory and resulted in the formulation of the sociology of associations that demands a switch of social sciences focus from society (that is, groups of humans) to collectives (that is, groups of humans and nonhumans). To quote from a commentary on Reassembling the Social (Latour 2005), "All the well-known structures of society are suddenly no-where to be found; instead, we now find concrete relations of humans and non-humans acting together" (Krarup and Block 2011: 43). Our social existence includes entities (agents, actors, actants) that have attributes. To define an entity "you have to deploy its attributes, that is, its network" (ibid., 46).

How does Castells's concept of networks interplay with Latour's actor-network? Latour mentioned this interplay in a speech in 2010 using one example: "If we accept to talk about a network revolution, it is because of the coincidence between the conceptual notion of network (action is radically redistributed) and the rematerialization allowed by digital techniques" (Latour 2010: 9). However, the concept of infrastructure, when added to the whole actor-network picture, complicates it. While we can be relatively sure that we understand what human is (or at least we can rely on the good old tradition and say that human is everything social sciences studied before Latour arrived), the attempt to define the nonhuman leads one to a slightly bewildered answer: well, nonhuman is ... everything else.

Recent studies of the infrastructure of the Panama Canal (Carse 2014) or public toilets in Ghana (Chalfin 2014) or other structures in other parts of the world show that literally everything can be the object of infrastructural studies: technology, organizations, power, media, and discourse, as mentioned above (as if it were not enough!). Also, all manifestations of the physical environment can be considered infrastructure-such as weather, temperature, distance, or space itself (cf. Ingold's [2000] dwelling perspective; similar ideas can be found in Viveiros de Castro [2004], Hastrup [2009], a.o.]).

The landscape and all its attributes-such as purity and pollution, danger and safety, beauty or ugliness, together with all of the previous examples-when spread through personal communication, or impersonal sheets of typographic paper, or collective memory, can also be the object of "infrastructural" studies. (To avoid turning this modest introduction into a library catalogue let me only make three references here: to the famous book by Mary Douglas [1966], to one by Keith Basso [1996], and to a lesser known but not less insightful book by Richard K. Nelson [1986].) 
We should not forget that all this has a diachronic dimension: that infrastructure comprises the past imprinted in individual and collective memory, written and oral history texts, and traditions and ideologies and that "infrastructure is fundamentally and always a relation, never a thing" (Star and Ruhleder 1994: 253).

Nor should we forget that "infrastructure is also always about the future, or different futures. Departing somewhat from the science and technology studies literature that emphasizes infrastructure as substrate of processes in the present, infrastructure in these frontier spaces [Latin America] continues to be entangled with promise, hope, possibility, and fear" (Hetherington and Campbell 2014: 193).

As Simone's people as infrastructure comes into the picture, the picture gets extended beyond any reasonable limits:

The notion of people as infrastructure ... emphasizes economic collaboration among residents seemingly marginalized from and immiserated by urban life. Infrastructure is commonly understood in physical terms, as reticulated systems of highways, pipes, wires, or cables.... By contrast, I wish to extend the notion of infrastructure directly to people's activities in the city. (Simone 2004: 407; italics added)

The term infrastructure is thus used in a much broader sense than simply as a designation for hard infrastructure: the physical components of interrelated systems providing commodities and services essential to enable, sustain, or enhance societal living conditions (Fulmer 2009). The term also covers all of the man-made world (sometimes called soft infrastructures): the financial system, transportation and supply system, the education system, the health-care system, leisure opportunities; it also covers climate and weather conditions that affect human behavior, and so forth. Moreover, under the concept of people as infrastructure (Simone 2004), all their perceptions, fears, hopes, and plans are included. Some call this invisible infrastructures (De Boeck 2012). Shall we introduce another new term and call it mental infrastructure? Will this term help us to deal with situations like those described in Zamyatina's article, in which the choice of the migration direction is shaped by economic conditions and opportunities, social networks, and also by self-assessments, worldviews, and value systems-that is, by invisible, or mental, infrastructure?

Infrastructure seems to become not only the key overarching concept of the present special issue of Sibirica but also a key concept of contemporary Arctic anthropology. Different understandings of 
infrastructure and different applications of this concept are so numerous that one is tempted to speak of infrastructuralism as a leading theory of the discipline.

$$
* \quad * \quad *
$$

Clearly, the question "What is infrastructure?" is the most difficult of all, and it has no concrete answer. Infrastructure means, in contemporary anthropological literature, too many different things (and nonthings) to allow consistent and productive use of this term. Apparently, a new theory is needed.

Let me avail myself of a parallel. More than a hundred years ago, linguistics was in a similarly difficult situation. Linguistic thought was buried under the avalanche of thousands of individual dialectological facts, suffered from seemingly endless fragmentation of its object, and was dragged into a whirlpool of hundreds of variables that caused people to speak differently. Then, Ferdinand de Saussure came and saved linguists by simply introducing two pairs of concepts. The first was the distinction between langue (language system) and parole (speech). Saussure demonstrated that this ocean of minor details that linguistics was sinking into had to do with speech, not with language systems, and that one could (and should) study language systems without paying any attention to speech variability. The second was the distinction between synchronic description of the language system and its diachronic dimension-that is, its history. Saussure postulated that no diachronic argument could be legitimately used to explain synchronic facts, and vice versa. These principles had the simplicity of a genius. Endless variability of speech does not mean that a language system is endlessly variable, and knowledge about an item's history has nothing to do with its structural function.

Linguists of the early twentieth century, with a sigh of relief, followed these ideas, and they have been used (with all sorts of modifications and improvements, of course) for the last 100 years. Let us remember, however, that if it were not for the heaps of facts accumulated by pre-Saussurean linguistics-meticulously collected, carefully described and cataloged-Saussure would have had nothing to build his theory on. As I have tried to show, the theoretical frameworks offered by Urry, Latour, Castels, De Boeck, and others are quite sufficient to allow one to notice and describe new facts, new interesting turns, or new connections that had been invisible before these theories were formulated. But it seems (as Latour himself claims ${ }^{2}$ ) that the next 
theoretical breakthrough will be possible only after a critical mass of facts is collected, cataloged, and organized in accordance with these theories. The present special issue of Sibirica is our modest contribution to this future database of facts.

\section{Acknowledgments}

This article is a part of the project "'Children of the Nineties': Strategies for the Present and Plans for the Future," funded by the Russian Science Foundation under grant no. 14-18-02136.

Nikolai Vakhtin is university professor at European University, St. Petersburg. Research interests: sociolinguistics and Arctic social studies. He has authored and edited several books, including Iazy ki narodov Severa $v 20$ veke: Ocherki iazykovogo sdviga [Languages of the peoples of the North in the twentieth century: Essays on language shift] (St. Petersburg: Dmitrii Bulanin, 2001); Albert Baiburin, Catriona Kelly and Nikolai Vakhtin, eds. Russian Cultural Anthropology after the Collapse of Communism (London and New York: Routledge, 2012); and Nikolai Vakhtin and Boris Firsov, eds., Public Debate in Russia: Matters of (Dis)order (Edinburgh: Edinburgh University Press, 2016). He is a member of the editorial boards of Antropologicheskii Forum, Voprosy iazykoznaniia, and Acta Borealia. E-mail: nvakhtin@ gmail.com

\section{Notes}

1. Karl Marx (1904: 11-12) wrote, "The mode of production in material life determines the general character of the social, political, and spiritual processes of life. It is not the consciousness of men that determines their existence but, on the contrary, their social existence determines their consciousness." The subtitle for this special issue, "Das Sein bestimmt das Bewusstsein?" has become a well-known quote attributed to Marx and translates as, "Does being determine consciousness?"

2. "Latour's ideal remains one of descriptivist empiricism, indeed of a self-confessedly radical type: 'just go on describing' seems to be his new master-rule of sociological method" (Krarup and Block 2011: 44). 


\section{References}

Ardener, Edwin. (1987) 2012. "Remote Areas: Some Theoretical Considerations." HAU: Journal of Ethnographic Theory 2 (1): 519-533.

Basso, Keith. 1996. Wisdom Sits in Places: Landscape and Language among the Western Apache. Santa Fe: University of New Mexico Press.

Carse, Ashley. 2014. Beyond the Big Ditch: Politics, Ecology and Infrastructure at the Panama Canal. Cambridge, MA: MIT Press, 2014.

Castells, Manuel. 1996. The Rise of the Network Society: The Information Age; Economy, Society and Culture. Vol. 1. Oxford: Blackwell.

Manuel Castells Interview: Conversations with History. 2001. Institute of International Studies, UC Berkeley. May 9. The Network Society and Organizational Change. http://globetrotter.berkeley.edu/people/Castells/ castells-con4.html (accessed 25 September, 2017).

Chalfin, Brenda. 2014. "Public Things, Excremental Politics, and the Infrastructure of Bare Life in Ghana's City of Tema." American Ethnologist 41 (1): 92-109.

De Boeck, Filip. 2012. "Infrastructure: Commentary from Philip De Boeck." Curated Collections, Cultural Anthropology Online, November. https://culanth. org/curated_collections/11-infrastructure/discussions/7-infrastructurecommentary-from-filip-de-boeck. (accessed 25 September, 2017)

Douglas, Mary. 1966. Purity and Danger: An Analysis of Concepts of Pollution and Taboo. London: Routledge.

Fulmer, Jeffrey. 2009. "What in the World Is Infrastructure?" Private Equity Investor/Infrastructure Investor, July/August, 30-32.

Hastrup, Kirsten. 2009. “The Nomadic Landscape: People in a Changing Arctic Environment." Geografisk Tidsskrift-Danish Journal of Geography 109 (2): 181-189.

Hetherington, Kregg, and Jeremy M. Campbell. 2014. "Nature, Infrastructure, and the State: Rethinking Development in Latin America." Journal of Latin American and Caribbean Anthropology 19 (2): 191-194, DOI:10.1111/jlca.12095

Humphrey, Caroline. 2014. “Izmenenie znachimosti udalennosti v sovremennoi Rossii" [The change of the meaning of 'remoteness' in modern Russia]. Etnograficheskoe obozrenie 3:8-24.

Ingold, Tim. 2000. The Perception of the Environment: Essays on Livelihood, Dwelling, and Skill. London: Routledge.

Krarup, Troels, and Anders Block. 2011. "Unfolding the Social: Quasi-actants, Virtual Theory, and the New Empiricism of Bruno Latour." Sociological Review 59 (1): 42-63, DOI: 10.1111/j.1467-954X.2010.01991.x

Latour, Bruno. 1988. The Pasteurization of France. Cambridge, MA: Harvard University Press.

Latour, Bruno. 1996. Aramis, or, The Love of Technology. Cambridge, MA: Harvard University Press. 
Latour, Bruno. 2005. Reassembling the Social: An Introduction to Actor-Network Theory. Oxford: Clarendon.

Latour, Bruno. 2010. "Networks, Societies, Spheres: Reflections of an ActorNetwork Theorist." Keynote speech presented at the International Seminar on Network Theory: Network Multidimensionality in the Digital Age, Annenberg School for Communication and Journalism, Los Angeles, 19 February. http://www.bruno-latour.fr/sites/default/files/121-CASTELLS-GB.pdf.

Marx, Karl. 1904. A Contribution to the Critique of Political Economy. Chicago: Charles H. Kerr.

Nelson, Richard K. 1986. Make Prayers to the Raven: A Koyukon View of the Northern Forest. Chicago: University of Chicago Press.

Simone, AbdouMaliq. 2004. "People as Infrastructure: Intersecting Fragments in Johannesburg." Public Culture 16 (3): 407-429.

Star, S. Leigh and Ruhleder, K. 1994. Steps towards an ecology of infrastructure: complex problems in design and access for large-scale collaborative systems, Proceedings of the 1994 ACM conference on Computer supported cooperative work CSCW '94, Publisher ACM Press, October 1994, pp. 253-264

Star, Susan Leigh, and Karen Ruhleder. 1996. "Steps towards an Ecology of Infrastructure: Design and Access for Large Information Spaces." Information Systems Research 7 (1): 111-134.

Urry, John. 2000. Sociology beyond Societies: Mobilities for the Twenty-First Century. London: Routledge.

Viveiros de Castro, Eduardo. 2004. "The Transformation of Objects into Subjects in Amerindian Ontologies." Common Knowledge 10 (3): 463-485. 